was at the Mediterranean naval base near Toulon with the bombing of several million dollars worth of reactor equipment intended for export to Iraq, West Germany and Belgium. Responsibility was claimed by a group of militant ecologists in a call to Le Monde. The caller said: "We have succeeded in ncutralising machines dangerous to human life." However. French officials arc reported as believing that the bombing may have been an Isracli action directed primarily against the Iraqi reactor programme.

In West Germany, 35.000 demonstrators at the Gorleben hearing into nuclear reprocessing plans in Lower Saxony chanted, "we all live in Pennsylvania." Inside the hearings, a French scientist. Yves Lenoir of the mining academy of Fountainbleau, walked out of the meeting of 60 international experts saying that the hearings were a sham and had no influence over the decision. Lenoir said that any discussion of safety that did not take into account the Harrisburg events was academic.

But the Ministry of the Interior in Bonn said that German safety standards were high compared with international standards but they would be "toughened up" drastically. "Utilities and the nuclear industry will have no chance to ease safety precautions." a spokesman said.

In Sweden the Opposition party demanded that the Ringhals lwo plant near Goteberg -a PWR similar to Harrisburg should be closed for inspection; and Premier Ola Ullsten announced a national referendum on the country's nuclear programme. Danish politicians urged greater debate before their country took a decision to build nuclear reactors, and in Belgium the mayor of the town of Huy, 40 miles south-cast of Brussels, ordered the closing of the $870 \mathrm{MW}$ reactor. Tihange 1, saying that the Harrisburg accident had shown the town's emergency preparations to be inadequate.
In Japan. Premier Masayoshi Ohira said there would be no change in Japan's programme which currently has 19 reactors producing $11 \%$ of the country's energy: But 100 demonstrators staged a sit-in at the Ministry of International Trade and Industry calling for a thorough inspection of all Japan's nuclear power plants. The ministry itself was holding an emergency meeting with officials from 15 areas to discuss nuclear safety measures.

In Eastern Europe, comment on Harrisburg was limited. Soviet television devoted 15 minutes to the event on 2 April saying. "the accident has provoked a profound anxiety and continues to alarm the American people. A particular indignation has been aroused by the fact that the energy monopolies, in scarching for profits, do not take the necessary measures in order to assure the safe functioning of nuclear power stations."

\title{
Guidelines should go, DNA meeting concludes
}

\section{Eleanor Lawrence reports on a meeting where biologists scourged themselves for going public on conjectural risks}

LAST week in the village of Wye, deep in the Kent countryside, an audience predominantly composed of molecular biologists overwhelmingly reiterated the now widely-held view that recombinant DNA research poses no special risks.

The meeting was convened by the Royal Society and COGENE, the Committee on Genetic Experimentation of the International Council of Scientific Unions. to discuss the status of recombinant DNA work and the guidelines controlling it.

Essentially most scientists working in the field now believe that the original fears were based on bad scientific judgment, and that recombinant DNA experiments at the very worst can pose no more hazard than that of working with the most dangerous organism involved in the experiment. Therefore. they argue. regulations for recombinant DNA research are unwarranted and should be abolished. The inconsistency inevitable in guidelines designed to guard against conjectural hazards and the bureaucracy involved in their implementation pose a threat to the freedom of scientific enquiry.

The scientific hasis for the change of heart appears to rest first on advice from experts in infectious diseases that it is virtually impossible to convert the laboratory strain of the common gut organism $E$. coli into an epidemic pathogen by the random insertion of a block of foreign genes.

The fear that the insertion of animal virus genes into $E$. coli would result in a new route for the virus to bypass normal host defences is now also heid to be groundless. The current conventional wisdom is that work with cloned viral DNA poses, if anything. even less risk than work with the virus itself, and that cloned viral DNA fragments offer the safest way to study the molecular biology of the most lethal viruses such as I assa or smallpox.

Joe Sambrook of Cold Spring Harbor Laboratory observed that had Professor Bedson been working in Birmingham with cloned smallpox sequences rather than the complete virus. both ho and Janet Parker would be alive today: (The World Health Organisation is indeed considering the possibility that cloned fragments of smallpox DNA might be the safest way of conserving the smallpox genome for posterity). Although little direct evidence addressing this question was available in 1977 -when the Ascot Workshop's recommendation of such views to the $\mathrm{NIH}$ was influential in gaining considerable relaxation of guidclines for work with animal viruses-experimental support in the case of certain IDNA viruses, at least, has recently been obtained from the $\mathrm{NIH}$ 'worst case' polyoma virus experiment (sce box).

Participants in the debate also marshal evolutionary arguments. such as the growing appreciation that genetic exchange occurs across wide species barriers in microorganisms. as general ammunition. But it is not clear that these arguments necessarily address the particular point that still worries those who see the need for guidelines. They ask to be assured that the specific product of any given recombinant DNA experiment is not going to be hazardous to those who may be exposed to it, either in the laboratory. or in the gencral environment.

Among those who call for the end of regulation a more subjective attitude is that expressed most forcibly by J. D. Watson of Cold Spring Harbor. Watson now attributes the call for the moratorium as mixture of fears over research with tumour viruses themselves and an attack of mild liberal guilt. and considers that he and this fellow signatorics displayed a complete lack of scientific judgment. "We were jackasses" he told the conference. "It was a decision I. regret: one that I am intellectually ashamed of". Watson adopted this position soon after the original 'Berg letter' was written.

Another signatory. Stanley' Cohen of Stanford University, also felt the group's original action was irresponsible on scientific grounds. as well as politically naive. It was based simply on a "lack of certainty there was no" risk" and was therefore an "irresponsible scientific argument".

The third signatory present. Norton 7.inder. holds a somewhat different view. Although he now thinks their original fears to be groundless, in the circumstances as they saw them at the time there was no other action that could be taken.

Given that they now largely have the support of their scientific colleagues on 
guideline committees, the problem now facing those who wish to get rid of public guidelines was neatly summed up by Mark Richmond, a member of the UK Genetic Manipulation Advisory Group. Publication of the Berg letter, he pointed out, was in effect a political act even though there had been no political intention. But through this political act the subject has lost its innocence, and it is now going to be hard for the scientists involved to regain a position in which their views can be regarded as objective.

"How are you going to reassure the public that you're not arguing from self-interest", said Richmond, "but that you are now arguing objectivelyparticularly when. looked at from the outside, you seem to make enormous quantum jumps between what you require for conditions at one time and what you required for the same experiments a couple of years ago".

R. Pritchard. Professor of Biochemistry at Leicester and a wellknown opponent of the UK GMAG reiterated his opinion that the effect of the Berg letter was largely due to the eminent names appended to it. and that its message could only be countermanded by the authors themselves. They should state publicly and unequivocally what they now believe. he said. to the loudest round of applause of the meeting.

Not all the participants, however. judged the display of public recantation before the Inquisition to be warranted. In the perception of a historian of science. Charles Weiner of MIT, the recombinant DNA debate has not been the wasteful and illborn episode it seems to most of those concerned.

Weiner has followed the tortuous course of the debate from the beginning and has collected in his Recombinant

\section{'Worst case' experiments show low risk}

THt: original fears which led to the call for a moratorium were largely prompted by the prospect that cloning animal viruses, and especially tumour viruses, would provide them with a new or more effective way of overcoming host defences. The first results, reported recently, from the $\mathrm{NIH}$ 'polyoma experiment' designed to test this proposition were reassuring. Tests of the infectivity of complete copies of polyoma DNA cloned in plasmids or phage lambda showed it to be non-infectious or much less infectious (by a factor of $\left.10^{4}\right)$ than polyoma virus itself.

One of the NIH experimenters, Dr M. Martin of the National Institute of Allergy and Infectious Diseases, told the Wye conference of results they now have on the tumorigenicity of cloned polyoma IDNA. E. coli carrying plasmids containing one copy of polyoma DNA produced no tumours when introduced into newborn hamsters; polyoma virus introduced in comparable conditions produces tumours in all animals infected.

DNA Archive at MIT much of the formal documentation, supplemented by the informal accounts of those involved. Although molecular biologists found the experience of coming face to face with the apprehensions of society a traumatic one, they have, in Weiner's opinion, come through with their science and honour relately unscathed.

Despite the trauma and despite the
The circular recombinant plasmid DNA itself produced a few tumours when given in quantities equivalent to $10^{6}$ times those at which polyoma virus is invariably tumorigenic. As expected from the previous infectivity experiments, bacteriophage lambdacontaining dimeric polyoma DNA also caused tumours in a few cases.

The NIH experiment was delayed first by the regulations against the cloning of animal viruses and then by a private legal suit brought against NIH which sought to prevent the experiment. A group of European scientists sponsored by EMBO to undertake similar polyoma infectivity experiments completed initial in vitro infectivity tests (which came to essentially the same conclusions as the NIH study) last year under the then less restrictive UK regulations, but have been unable to carry out animal infectivity or tumorigenicity tests because of the lack of any approved facility for such animal experiments in Europe.

In contrast to the US team they werc able to obtain dimeric polyoma DNA cloned in plasmids the NIH scientists could only obtain dimeric polyoma inserts in lambda) which will now be tested for animal infectivity and tumorigenicity at Fort Detrick.

bureaucracy said Weiner, recombinant DNA research flourishes. Has the whoie debate and its attendant publicity, he wondered, stimulated rather than repressed the research? But he was concerned at the attitude he now sees amongst younger scientists. to whom the message of the recombinant DNA debate now seems to be "shut up or be shut down".

\section{US regulators countenance abolishment of the guidelines}

InICATtoNs that the administrators most closely concerned are sympathetic to the efforts of the US scientific community to disentangle itself from the coils of recombinant DNA guidelines were provided by the statement at the conference from the Director of NIH, Donald Fredrickson.

Fredrickson's decision to go public on the proposed guidelines early in 1976 exposed the scientists to the full force of a public debate. But Fredrickson maintains that this was the only way to release the rising tension and "to prepare to defend whatever actions would be taken. against certain criticism".

The first NIH guidelines were released in June 1976. and greatiy relaxed guidelines came into force early this year. In his Wye address, Fredrickson described the latest guidc- lines as a "new set of rules painfully formulated during this unprecedented curtailment of experimentation in biology".

In his view one of the important achievements of the revision was to provide for continuous and orderiy evolution of the rules-"even to their eventual elimination when the need passes". Further revisions are due to come into force within the next few weeks. notably the approval of strains of Bacillus substilis and Succharomyces cerevisiae host-vector systems for various levels of containment, a provision hitherto lacking in the NIH guidelines.

H. DeWitt Stetten, former Chairman of the Director's Recombinant DNA Advisory Committee, used his talk to describe his personal route to disenchantment. After battling with the myriad inconsistencies embodied in the first guidelines he eventually came to the conclusion that they had "got off the track badly" and were doing things that were very wrong-given that the mission of NIH was to support and encourage research.

He decided that the hazards had becn overstated as no one could give him any evidence that there was any hazard. He concluded that "we had erected a bastion against a phantom". and that the barriers built to exclude ghosts were composed of scientists' time. effort and money. He has proposed that the guidelines be reduced to one simple rulc: "the appropriate conditions of containment for recombinant DNA experiments should be those of the most virulent microorganism entering into the experiment". 